\title{
The Positive Aspects of Attention-Deficit/Hyperactivity Disorder among Famous People
}

\author{
Jong Won Lee ${ }^{1}$, Kyunghoon Seo', and Geon Ho Bahn ${ }^{2} \bowtie$
}

${ }^{1}$ Department of Psychiatry, Kyung Hee University Hospital, Seoul, Republic of Korea

${ }^{2}$ Department of Psychiatry, Kyung Hee University School of Medicine, Seoul, Republic of Korea

Psychiatry Investig 2020;17(5):424-431

https://doi.org/10.30773/pi.2020.0036

In the 'Acknowledgements' section on page 430 of the original article, the grant number was missed.

The funding resource should be:

This work was supported by a grant from Kyung Hee University in 2019 (KHU-20191239).

@ This is an Open Access article distributed under the terms of the Creative Commons Attribution Non-Commercial License (http://creativecommons.org/licenses/bync/4.0) which permits unrestricted non-commercial use, distribution, and reproduction in any medium, provided the original work is properly cited. 